\title{
Soil Type Influence Nutrient Availability, Microbial Metabolic Diversity, Eubacterial and Diazotroph Abundance in Chickpea Rhizosphere
}

Sneha Gowda

Indian Agricultural Research Institute

Karivaradharajan Swarnalakshmi

Indian Agricultural Research Institute

Meenakshi Sharma

Indian Agricultural Research Institute

Kedharnath Reddy

Indian Agricultural Research Institute

Arpan Bhoumik

Indian Agricultural Statistics Research Institute

Archna Suman

Indian Agricultural Research Institute

Annapurna Kannepalli ( $\square$ annapurna96@gmail.com )

ICAR-Indian Agricultural Research Institute https://orcid.org/0000-0001-7297-9180

Research Article

Keywords: Chickpea, Metabolic diversity, BIOLOG, PLFA, Diazotrophs

Posted Date: April 26th, 2021

DOI: https://doi.org/10.21203/rs.3.rs-285962/v1

License: (c) (i) This work is licensed under a Creative Commons Attribution 4.0 International License. Read Full License 


\section{Abstract}

Rhizosphere microbial communities are dynamic and play a crucial role in diverse biochemical processes and nutrient cycling. Soil type and cultivar modulate the compositionof rhizosphere microbial communities. Changes in the community composition significantly alter microbial function and ecological process. We examined the influence of soil type on eubacterial and diazotrophic community abundance and microbial metabolic potential in chickpea (cv. BG 372 and cv. BG 256) rhizosphere. The total eubacterial and diazotrophic community as estimated through 16S rDNA and nifH gene copy numbers using qPCR showed the soil type influence with clear rhizosphere effect on gene abundance. PLFA study has shown the variation in microbial community structure with different soil types. Differential influence of soil types and cultivar on the ratio of Gram positive to Gram negative bacteria was observed with most rhizosphere soils corresponding to higher ratios than bulk soil. The rhizosphere microbial activities (urease, dehydrogenase, alkaline phosphatase and beta-glucosidase) were also assessed as an indicator of microbial metabolic diversity. Principal component analysis and K-means non-hierarchical cluster mapping grouped soils into three categories, each having different soil enzyme activity or edaphic drivers. Soil type and cultivar influence on average substrate utilization pattern analyzed through community level physiological profiling (CLPP) was found to be higher for rhizosphere soils than bulk soils. The soil nutrient studies revealed that both soil type and cultivar influenced the available N, P, K and organic carbon content of rhizosphere soil. Our study signifies that soil type and cultivarjointly influenced soil microbial community abundance and their metabolic potential.

\section{Introduction}

Soil is the home for prodigious number of living organisms and as far as the plant growth and soil properties are concerned, microbial communities inhabiting rhizosphere region play a crucial role in diverse biochemical processes and nutrient cycling. The rhizosphere, as a focus of soil microbial communities is dynamic and plant-microbe interactions are frequent here. The living plant roots secrete large quantity of organic compounds that in turn stimulate a more abundance, higher microbial diversity and enzyme activities in rhizosphere (Smalla et al. 2001). The bulk samples, soil outside rhizosphere, is not penetrated by plant roots and shows low rates of nutrient transformation and microbial activity compared to active rhizosphere (Ai et al. 2012). Rhizosphere microflora can improve the soil quality and crop performance. Many studies have focused on traditional culturable techniques to study the rhizosphere microbial diversity and function, 'great plate count anomaly' states that a greater fraction (95-99\%) of microbial community involved in rhizosphere process is unculturable (Nichols 2007). Advanced analytical techniques such as Amplified Ribosomal DNA Restriction Analysis (ARDRA, Gich et al. 2000), BOX PCR (Satyaprakash and Annapurna 2006), Denaturing Gradient Gel Electrophoresis (DGGE, Miller et al. 1999), Quantitative PCR (Fierer et al. 2005), phospholipid fatty acid (PLFA, Guckert and White 1986), and community level physiological profiling (CLPP, Preston-Mafham et al. 2002) are used to examine the diversity of fingerprints allowing for more detailed analyses of abundance and activities of soil microbial communities (Mittal and Virdi 2002).

Chickpea (Cicer arietinum L.) popularly known as gram or Bengal gram is an annual legume and mostly grown under rainfed conditions in arid and semi-arid regions in India. The world production of chickpea accounted for 14.24 million tonnes, with India alone accounting for $69.7 \%$ (9.93 million tonnes) of total production (FAOSTAT 2019). Globally, chickpea has yield levels of about $920 \mathrm{~kg} \mathrm{ha}^{-1}$. Chickpea being a leguminous crop replenishes soil fertility through Biological Nitrogen Fixation (BNF) by forming symbiotic association with effective Mesorhizobium strains. Under favorable conditions, the symbiotic nitrogen fixation can supply up to $85 \%$ of the $\mathrm{N}$ required by chickpea crop (Walley et al. 2005). The crop can also assemble root-associated microbial communities primarily derived from the rhizosphere soil (Reinhold-Hurek et al. 2015). These microbes could improve plant growth and health as this crop is generally grown under low chemical input. The beneficial function of rhizosphere microbial communities includes improved nutrient uptake, plant hormone production, imparting disease resistance and stress tolerance (Mendes et al. 2011; Kwak et al. 2018; Swarnalakshmi et al. 2020). The microbial abundance and function are known to be impacted by various ecological as well as plant factors (Pii et al. 2016; Liu et al. 2019). The various root exudate compounds secreted by the different cultivars were reported to influence the diversity and function of root associated microbial communities in rhizosphere soil (Sasse et al. 2018; Lundberg et al. 2018). Soil characteristics such as organic carbon and nutrient level have pronounced effect on microbial abundance and performance (Hu et al. 2014; Zhu et al. 2015).

A number of methods are employed to study and quantify microbial diversity and their function ranging from physiological to molecular techniques. It is essential to use a combination of approaches for accurate results because no single approach can provide neither a complete picture of the type of microbes present nor their relative abundance within each of those types. The soil type mediated metabolic diversity of microbial communities associated with chickpea rhizosphere has never been explored. Hence, the present investigation is focused to study the influence of cultivarsand soil types on the nutrient availability, metabolic potential and microbial abundance associated with chickpea rhizosphere. We applied analyses of PLFA and CLPP in order to evaluate the microbial community structure and their functional diversity of soils collected from different regions across the country where chickpea is grown as part of cropping system. The influence of soil types on the eubacterial and diazotrophic abundance was determined using qPCR assays. In addition, soil microbial enzyme activities and nutrient content in the rhizosphere soil were assessed to estimate the rhizosphere microbial function.

\section{Material And Methods Experimental Design}

A pot experiment was carried out at National Phytotron facility, ICAR-Indian Agricultural Research Institute (IARI), New Delhi during rabi 2018-19. Soils were collected from chickpea growing regions of different agro-climatic zones of India. The 4" size pots were filled with finely ground soil samples of different locations. Location details along with chemical and enzyme activities of initial soil samples are given in the Table 1. The available $\mathrm{N}$ content of the collected soil samples was found to be low ( $<280 \mathrm{~kg} \mathrm{ha}^{-1}$ ). The available $\mathrm{K}$ at three locations viz Dharwad, New Delhi site 2 and Pune Site 1 was low and soils collected from Jharkhand, New Delhi site 1, Haryana, Varanasi, Pune site 2 and Kanpur showed medium range. Organic $\mathrm{C}$ content of all soils was in the low range. pH of the soils varied from neutral to alkaline. Two chickpea cultivars viz., BG-256 and BG-372 were grown in all soil types and the influence of cultivar was compared with control pots without plants (Bulk soil). Thus a total of 27 treatments $(9 \times 3)$ were replicated three times (completely randomized design - CRD).

Page $2 / 15$ 
Each pot was sown with 3 seeds with equal spacing and irrigation was given to maintain $60 \%$ water holding capacity. The rhizosphere soil samples as well as bulk soil (control) were collected at 60 days after sowing (vegetative stage). The soil samples were homogenized and passed through 2 mm sieve. The soil enzyme analysis was carried out in fresh samples and sub-samples were stored at $-80^{\circ} \mathrm{C}$ for microbial PLFA, CLPP and qPCR analysis, while another set of sub-samples were air-dried and passed through $0.2 \mathrm{~mm}$ sieve for analysis of soil nutrient content.

Table 1

Chemical and biological properties of initial soil samples collected from different chickpea growing regions

\begin{tabular}{|c|c|c|c|c|c|c|c|c|c|c|c|}
\hline Locations & $\begin{array}{l}\text { Previous } \\
\text { Crop }\end{array}$ & $\begin{array}{l}\text { Available } \\
\mathrm{N}(\mathrm{kg} \\
\left.\mathrm{ha}^{-1}\right)\end{array}$ & $\begin{array}{l}\text { Available } \\
\mathrm{P}(\mathrm{kg} \\
\left.\mathrm{ha}^{-1}\right)\end{array}$ & $\begin{array}{l}\text { Available } \\
\text { K } \\
\text { (kg ha- } \\
\left.{ }^{1}\right)\end{array}$ & $\mathrm{pH}$ & $\begin{array}{l}E C \\
\text { (ds } \\
m^{-} \\
\left.{ }^{1}\right)\end{array}$ & $\begin{array}{l}\text { Organic } \\
\text { carbon } \\
\text { (g kg- } \\
\left.{ }^{1}\right)\end{array}$ & $\begin{array}{l}\text { Dehydrogenase } \\
\left(\mu \mathrm{g} \text { TPF } \mathrm{g}^{-1}\right. \\
\left.\text { soil }^{-1}\right)\end{array}$ & $\begin{array}{l}\text { Urease } \\
(\mu \mathrm{g} \\
\mathrm{NH}_{4}{ }^{-} \mathrm{N} \\
\mathrm{g}^{-1} \\
{\text { soil } \mathrm{h}^{-}}^{1} \\
\left.{ }^{1}\right)\end{array}$ & $\begin{array}{l}\text { Alkaline } \\
\text { Phosphatase } \\
\left(\mu \mathrm{g} \mathrm{PNP} \mathrm{g}^{-1}\right. \\
\text { soil } \mathrm{h}^{-1} \text { ) }\end{array}$ & $\begin{array}{l}\beta- \\
\text { Glucosidase } \\
\left(\mu g^{-1} \text { soil }\right. \\
\left.h^{-1}\right)\end{array}$ \\
\hline $\begin{array}{l}\text { Dharwad, } \\
\text { Karnataka }\end{array}$ & Fallow & 103.66 & 17.20 & 196.71 & 7.61 & 0.46 & 4.89 & 31.67 & 62.69 & 123.9 & 11.23 \\
\hline $\begin{array}{l}\text { Rajnandgaon, } \\
\text { Jharkhand }\end{array}$ & Rice & 95.08 & 13.11 & 324.44 & 7.92 & 0.51 & 9.11 & 48.23 & 15.24 & 111.24 & 76.95 \\
\hline $\begin{array}{l}\text { New Delhi } \\
\text { site I, } \\
\text { Delhi }\end{array}$ & Rice & 71.93 & 20.22 & 691.8 & 7.6 & 0.45 & 7.04 & 40.52 & 41.97 & 55.98 & 5.77 \\
\hline $\begin{array}{l}\text { New Delhi } \\
\text { site II, } \\
\text { Delhi }\end{array}$ & Maize & 151.16 & 6.35 & 163.38 & 7.05 & 0.48 & 7.64 & 13.17 & 30.73 & 167.18 & 24.36 \\
\hline $\begin{array}{l}\text { Gangwa, } \\
\text { Haryana }\end{array}$ & Bajra & 170.89 & 7.95 & 311.29 & 8.12 & 0.38 & 12.56 & 29.63 & 25.44 & 134.76 & 12.89 \\
\hline $\begin{array}{l}\text { Varanasi, } \\
\text { Uttar Pradesh }\end{array}$ & Rice & 112.91 & 13.31 & 703.6 & 7.95 & 0.34 & 11.13 & 35.75 & 9.95 & 72.68 & 10.96 \\
\hline $\begin{array}{l}\text { Pune site I, } \\
\text { Maharashtra }\end{array}$ & Fallow & 122.89 & 4.76 & 149.01 & 7.54 & 0.49 & 8.14 & 64.9 & 20.81 & 195.39 & 20.63 \\
\hline $\begin{array}{l}\text { Pune site II, } \\
\text { Maharashtra }\end{array}$ & Maize & 116.35 & 5.65 & 281.97 & 7.96 & 0.52 & 18.47 & 32.58 & 30.11 & 126.42 & 7.41 \\
\hline $\begin{array}{l}\text { Kanpur, } \\
\text { Uttar Pradesh }\end{array}$ & Bajra & 88.90 & 11.23 & 691.71 & 7.82 & 0.28 & 8.33 & 49.2 & 16.58 & 47.81 & 9.06 \\
\hline $\mathrm{SE}(\mathrm{m})$ & & 1.61 & 0.40 & 7.18 & 0.09 & 0.01 & 0.24 & 3.54 & 0.07 & 1.39 & 0.29 \\
\hline$C D(p=0.05)$ & & 4.81 & 1.19 & 23.29 & 0.30 & 0.02 & 0.77 & 11.49 & 0.19 & 3.86 & 2.48 \\
\hline
\end{tabular}

\section{Soil nutrient analysis}

Available Nitrogen was estimated using alkaline permanganate procedure described by Subbiah and Asija (1956). Available P was estimated by standard method described by Olsen et al (1954). The available potassium content in the soil was detected using flame photometer against the known standards (Jackson 1973). Soil organic carbon was determined by Walkley and Black's method (1934). EC and pH were determined by method as described by Smith and Doran (1996).

\section{Soil Enzyme analysis}

The activities of four soil enzymes viz dehydrogenase (Casida 1977), urease (Tabatabai and Bremner 1972), alkaline phosphatase (Tabatabai and Bremner,1969) and $\beta$-glucosidase (Eivazi and Tabatabai 1988) activities were measured as previously described. The dehydrogenase activity was analyzed by 2-3-5 Triphenyl tetrazolium chloride (TTC) reduction technique by adding $1 \mathrm{~mL} 3 \%$ TTC to $6.0 \mathrm{~g}$ soil sample followed by methanol extraction after $24 \mathrm{~h}$ of incubation at $37^{\circ} \mathrm{C}$ in dark. The aliquot containing TPF was measured at $485 \mathrm{~nm}$. Urease activity was assayed by weighing $5 \mathrm{~g}$ soil sample followed by addition of $2.5 \mathrm{~mL}$ urea solution ( $0.5 \%)$. The samples were incubated at $37^{\circ} \mathrm{C}$ for $2 \mathrm{~h}$ and followed by $\mathrm{KCl}(1 \mathrm{M})$ extraction. The contents were filtered and $5 \mathrm{~mL}$ sodium salicylate and $2 \mathrm{~mL}$ sodium dichloro-isocyanide solution was added to the filtrate followed by incubation for 30 min. The green color developed was measured at $690 \mathrm{~nm}$. Alkaline phosphatase activity was measured by homogenizing the pre-weighed (2.0 g) soil with $4 \mathrm{~mL}$ MUB (Modified Universal Buffer, $\mathrm{pH} 11$ ) solution and $1 \mathrm{ml}$ p-nitrophenylphosphate $(0.025 \mathrm{M})$. The samples were incubated at $37^{\circ} \mathrm{C}$ for $1 \mathrm{~h}$ and $1 \mathrm{~mL}$ of $0.5 \mathrm{M} \mathrm{CaCl} 2$ and $4 \mathrm{~mL}$ of $0.5 \mathrm{M} \mathrm{NaOH}$ were added. The contents were filtered and the yellow color developed was measured at $400 \mathrm{~nm}$. The $\beta$-glucosidase activity was measured by mixing the known amount of soil with $4 \mathrm{~mL}$ MUB $(\mathrm{pH} 6)$ solution and $1 \mathrm{~mL}$ of $\mathrm{p}$ - nitrophenyl $\beta$-D-glucopyranoside (25 mM) solution to known amount of soil followed by extracting the content with $0.1 \mathrm{M}$ Tris buffer (pH 12). The yellow color developed was measured at $400 \mathrm{~nm}$ (Eivazi and Tabatabai 1988). Microbial biomass carbon (MBC) was estimated bychloroform fumigation extraction method (Vance et al. 1987).

\section{Structural diversity of microbiota by PLFA profiling}


Lipid extraction and PLFA analyses of soil samples were performed using the modified Bligh and Dyer-method (Bligh and Dyer 1959; Frostegard et al.1991). Briefly, $2.0 \mathrm{~g}$ of freeze-dried soil was extracted with a chloroform-methanol-citrate buffer mixture (1:2:0.8), and the phospholipids were separated on a silicic acid column. The phospholipids were subjected to a mild alkaline methanolysis and the resulting fatty acid methyl esters were prepared according to the MIDI protocol. The total PLFA concentration was expressed as nmol g ${ }^{-1}$ soil.

\section{Eubacterial and diazotrophic abundance by RTPCR}

SYBR green technology for quantitative-PCR (C1000 CFX 96 Real-Time PCR System, Biorad) was used to quantify the number of eubacterial (16S rDNA) and diazotrophic (nifH) gene copies present in the community DNA extracts of soil samples. Total DNA from bulk and chickpea rhizosphere soil was extracted using Power Soil DNA kit (MoBio). All extracts were stored at $-80^{\circ} \mathrm{C}$ until use. DNA quality was checked by running samples in Qubit fluorometer. The primer pair CAACGCGAAGAACCTTAC (F)/CGGTGTGTACAAGGCCCGGGAACG(R)andAAAGGYGGWATCGGYAARTCCACC(F)/TTGTTSGCSGCRTACATSGCCATCAT(R) were used for specific amplification of the bacterial 16S rDNA (Fierer et al. 2005) and nifH (Poly et al. 2001) genes respectively. The qPCR reaction mixture for 16S rDNA amplification consisted of $7.5 \mu \mathrm{L}$ master mix containing $1 \mathrm{X}$ SYBER green, $0.3 \mu \mathrm{L}$ of each primer $(10 \mu \mathrm{M}), 3 \mu \mathrm{L}$ DNA and $3.9 \mu \mathrm{L}$ water. The qPCR program for bacterial $16 \mathrm{~S}$ rDNA gene began with an initial step of $15 \mathrm{~min}$ at $95^{\circ} \mathrm{C}$, followed by 40 cycles of denaturation at $95^{\circ} \mathrm{C}$ for $30 \mathrm{~s}$, annealing at $54^{\circ} \mathrm{C}$ for $30 \mathrm{~s}$, extension at $72^{\circ} \mathrm{C} 1 \mathrm{~min}$ followed by 1 cycle of extension at $72^{\circ} \mathrm{C}$ for $5 \mathrm{~min}$ and denaturation at $95^{\circ} \mathrm{C}$ for 1 min, annealing at $54^{\circ} \mathrm{C}$ for $30 \mathrm{~s}$ and final extension at $95^{\circ} \mathrm{C}$ for $30 \mathrm{~s}$. The nifH gene qPCR reaction mixture consisted of $12.5 \mu \mathrm{L}$ master mix containing $1 \mathrm{X}$ SYBER green, $0.25 \mu \mathrm{L}$ of each primer (10 $\left.\mu \mathrm{M}\right)$, $5 \mu \mathrm{L}$ DNA and $7 \mu \mathrm{L}$ water. The nifH gene copy number was amplified with an initial step of $15 \mathrm{~min}$ at $95^{\circ} \mathrm{C}$, followed by 40 cycles of denaturation at $94^{\circ} \mathrm{C}$ for $30 \mathrm{~s}$, annealing at $60^{\circ} \mathrm{C}$ for $45 \mathrm{~s}$, extension at $72^{\circ} \mathrm{C}$ for $45 \mathrm{~s}$ followed by 1 cycle of final extension at $72^{\circ} \mathrm{C}$ for 10 min, annealing at $68^{\circ} \mathrm{C}$ for $5 \mathrm{~s}$ and denaturation at $95^{\circ} \mathrm{C}$ for $50 \mathrm{~s}$. Fluorescence data were recorded during the qPCR run and a cycle threshold $\left(\mathrm{C}_{t}\right)$ was determined automatically with the SDS software package (Biorad). Real-time amplification plots of the products were monitored for each reaction for quality control. To generate standard curves for the transformation of $C_{t}$ values into absolute units (total number of gene copies), 10-fold serial dilution (10 $10^{1}$ to $\left.10^{8}\right)$ of known copy numbers of pGM-T easy (Promega) cloned template for 16S rDNA and nifH gene was generated. The standard curves were run simultaneously and the log-linear correlation coefficients, $R^{2}$ between the number of $16 \mathrm{~S}$ rDNA and nifH gene copies and $\mathrm{C}_{\mathrm{t}}$ values were $>0.98$ in all standard curves.

\section{Functional potential of microbiota using CLPPAnalysis}

The commercially available EcoPlates of BIOLOG Inc. were used to study the metabolic diversity of soil microbial communities using C-substrate utilization. Each BIOLOG plate contained $31 \mathrm{C}$ substrates with one control in triplicates. Bulk and rhizosphere soil suspension was prepared for each sample by adding 10 $\mathrm{g}$ of homogenized soil in $250 \mathrm{~mL}$ flasks with $90 \mathrm{~mL}$ of sterile $0.85 \% \mathrm{NaCl}$ solution. The flasks were shaken for $30 \mathrm{~min}$ on rotary shaker at $120 \mathrm{rpm}$. The $\mathrm{NaCl}$ extracts were allowed to settle for $20 \mathrm{~min}$ to clear the supernatant, which was serially diluted to $10^{-3}$. Ecoplates were inoculated with $125 \mu \mathrm{L}$ per well with $10^{-3}$ dilution and were incubated at $30^{\circ} \mathrm{C}$. The color change was measured at $590 \mathrm{~nm}$ at $72 \mathrm{~h}$ using BIOLOG Micro-Station reader. Microbial activity of BIOLOG Ecoplates was expressed as Average Well Color Development (AWCD) (Garland and Mills 1991), which was derived from the mean difference among the OD values of the 31 response wells (R) and the OD value of control well (C). The AWCD was calculated using the formula: AWCD = $\Sigma(R-C) / 31(\mathrm{Li}$ et al. 2012$)$. The functional diversity of microbial communities was calculated by Shannon-diversity $(H)$ and Mclntosh evenness $(U)$. Shannon-diversity $(H)$ was quantified by the formula: $\mathrm{H}=-\Sigma \mathrm{pi}(\mathrm{Inpi})$. Where, $\mathrm{pi}=$ proportional color development of the well over total color development of all wells of a plate. Mclntosh Evenness (U) was calculated by the formula: $U=\sqrt{\Sigma}\left(n_{i}\right)^{2}$, where $n$ represents therelative absorbance value for each $C$ source (Garland 1996).

\section{Plant growth and nutrient uptake}

The chickpea plants were uprooted at vegetative stage. The root and shoot tissues were dried at $65^{\circ} \mathrm{C}$ until complete removal of moisture. The dried shoots and roots were weighed using a weighing balance and the dry weight was expressed in milligram per plant. The dried plant tissues were finely ground for nitrogen and phosphorus analysis. $\mathrm{N}$ content was determined by a micro Kjeldahl method (Yuen and Pollard 1953) and P content was estimated by vanadomolybdate method (Jackson 1973).

\section{Statistical analysis}

Data for soil nutrient status, enzyme activities and plant growth attributes were subjected to ANOVA and two factor analysis. For analyzing the parameters between different locations, data was subjected to combined analysis and principal component analysis (PCA) using SAS software 9.4. Data for qPCR, PLFA and CLPP were subjected to agglomerative hierarchical clustering techniquesand principal component analysis (PCA) using R version 3.4.4 (2018-03-15), Platform: x86_64-w64-mingw32/x64 (64-bit).

\section{Results}

The mean values of soil chemical and enzyme properties for different locations is given in Table 2. Though the chickpea was grown under controlled conditions at New Delhi, our results showed different soil type had varied chemical and biological properties. Among the locations, available $\mathrm{N}$ content at New Delhisite II (235.55 kg ha-1) showed higher mean value and lowest value was recorded with New Delhisite I ( $\left.96.17 \mathrm{~kg} \mathrm{ha}^{-1}\right)$ in which rice and maize were the previous crop respectively. Available P content was more in Dharwad soil ( $28.87 \mathrm{~kg} \mathrm{ha}^{-1}$ ) and lowest value was recorded in soils collected from Kanpur location $\left(9.46 \mathrm{~kg} \mathrm{ha}^{-1}\right)$. Varanasi location $\left(512.04 \mathrm{~kg} \mathrm{ha}^{-1}\right)$ showed highest available $\mathrm{K}$ whereas lowest reading was recorded with Rajnandgaon (351.05 $\mathrm{kg}$ $\left.\mathrm{ha}^{-1}\right)$. Organic $\mathrm{C}$ was found to be higher in Kanpur $\left(12.57 \mathrm{~g} \mathrm{~kg}^{-1}\right)$ and Pune site II $\left(12.49 \mathrm{~g} \mathrm{~kg}^{-1}\right)$ and Rajnandgaon $\left(7.75 \mathrm{~g} \mathrm{~kg}^{-1}\right)$ recorded lowest value. The soil $\mathrm{pH}$ varied from 7.81(Gangwa) to 8.16 (Kanpur) and was neutral to alkaline. The electrical conductivity of different soils varied from $0.34 \mathrm{dSm}{ }^{-1}$ (IARI site 1 ) to $0.81 \mathrm{dS} \mathrm{m}^{-1}$ (IARI site II). The Dehydrogenase activity of soil was highest in Dharwad soil (71.67 $\mu \mathrm{g} \mathrm{TPF} \mathrm{g}^{-1}$ soil h$\left.^{-1}\right)$ and least in Gangwa soil (27.99 $\mu \mathrm{g}$ TPF $\mathrm{g}^{-1}$ soil $\left.^{-1}\right)$. Urease enzyme was higher in New Delhisite I $\left(36.8 \mu \mathrm{g} \mathrm{NH}_{4}^{-} \mathrm{N} \mathrm{g}^{-1}\right.$ soilh $\left.^{-1}\right)$ and lowest in Varanasi soil $\left(14.948 \mu \mathrm{g} \mathrm{NH}{ }_{4}^{-} \mathrm{N} \mathrm{g}^{-1}\right.$ soil h$\left.^{-1}\right)$. New Delhi 
site I showed higher alkaline phosphatase activity $\left(190.87 \mu \mathrm{g} \mathrm{PNP} \mathrm{g}{ }^{-1}\right.$ soil h$\left.^{-1}\right)$ and lowest in Kanpur soil $\left(73.66 \mu \mathrm{g} \mathrm{PNP} \mathrm{g}{ }^{-1}\right.$ soil $\left.^{-1}\right)$. Highest $\beta$-glucosidase activity is recorded with New Delhi site II $\left(23.2 \mu \mathrm{g} \mathrm{PNP} \mathrm{g}{ }^{-1}\right.$ soil h$\left.^{-1}\right)$ and least with New Delhi site I $\left(8.25 \mu \mathrm{g} \mathrm{PNP} \mathrm{g}{ }^{-1}\right.$ soil h$\left.{ }^{-1}\right)$. Among the different locations, the maximum microbial biomass carbon was recorded with New Delhi site $1\left(105.65 \mathrm{\mu g} \mathrm{g}^{-1}\right.$ soil day ${ }^{-1}$ ) whereas Pune site 1 recorded least value i.e. $47.74 \mu \mathrm{g}$ $\mathrm{g}^{-1}$ soil day ${ }^{-1}$.

Table 2

Nutrient availability and soil microbial activity of chickpea rhizosphere in different soils at vegetative stage in pot experiment

\begin{tabular}{|c|c|c|c|c|c|c|c|c|c|c|c|}
\hline Locations & $\begin{array}{l}\text { Available } \\
\mathrm{N}\left(\mathrm{kg} \mathrm{ha}^{-}\right. \\
\text {1) }\end{array}$ & $\begin{array}{l}\text { Available } \\
\mathrm{P} \text { ( kg ha- } \\
\text { 1) }\end{array}$ & $\begin{array}{l}\text { Available } \\
\mathrm{K}\left(\mathrm{kg} \mathrm{ha}^{-}\right. \\
\text {1) }\end{array}$ & $\begin{array}{l}\text { Organic } \\
\text { cabon } \\
(\mathrm{g} \mathrm{kg}- \\
\left.{ }^{1}\right)\end{array}$ & $\mathrm{pH}$ & $\begin{array}{l}\text { EC } \\
\text { (ds } \\
\mathrm{m}^{-} \\
1 \text { ) }\end{array}$ & $\begin{array}{l}\text { Dehydrogenase } \\
\left(\mu \mathrm{g} \mathrm{TPF} \mathrm{g} \mathrm{g}^{-1}\right. \\
\left.\text { soil }^{-1}\right)\end{array}$ & $\begin{array}{l}\text { Urease } \\
(\mu \mathrm{g} \\
\mathrm{NH}_{4}{ }^{-} \mathrm{N} \\
\mathrm{g}^{-1} \text { soil } \\
\left.\mathrm{h}^{-1}\right)\end{array}$ & 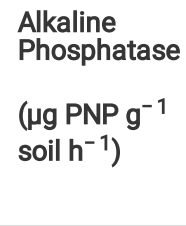 & $\begin{array}{l}\beta- \\
\text { Glucosidase } \\
\left(\mu g^{-1} \text { soil }\right. \\
\left.h^{-1}\right)\end{array}$ & $\begin{array}{l}\text { MBC } \\
\left(\mu \mathrm{g} \mathrm{g}^{-}\right. \\
{ }^{1} \text { soil }^{-1} \\
\left.\text { day }^{-1}\right)\end{array}$ \\
\hline Dharwad & 160.28 & 28.87 & 426.43 & 6.92 & 7.89 & 0.63 & 71.67 & 33.60 & 111.39 & 16.81 & 88.48 \\
\hline Rajnandgaon & 143.56 & 17.92 & 351.05 & 7.75 & 7.82 & 0.39 & 62.02 & 16.19 & 118.94 & 9.51 & 90.55 \\
\hline $\begin{array}{l}\text { New Delhi } \\
\text { site I }\end{array}$ & 96.17 & 15.93 & 506.59 & 8.78 & 8.01 & 0.34 & 54.84 & 36.80 & 74.24 & 8.25 & 105.65 \\
\hline $\begin{array}{l}\text { New Delhi } \\
\text { site II }\end{array}$ & 235.55 & 19.41 & 389.50 & 10.41 & 7.68 & 0.81 & 25.85 & 19.53 & 190.87 & 23.20 & 78.85 \\
\hline Gangwa & 200.70 & 11.95 & 370.62 & 10.68 & 7.81 & 0.66 & 27.99 & 20.93 & 129.71 & 13.31 & 62.57 \\
\hline Varanasi & 139.38 & 9.96 & 512.04 & 12.09 & 8.13 & 0.63 & 36.78 & 14.94 & 92.61 & 12.10 & 94.86 \\
\hline Pune site I & 203.49 & 14.93 & 383.55 & 11.17 & 7.97 & 0.80 & 55.62 & 21.17 & 178.01 & 18.40 & 47.74 \\
\hline Pune site II & 165.86 & 14.93 & 360.80 & 12.49 & 8.06 & 0.58 & 56.08 & 18.45 & 108.20 & 11.85 & 56.67 \\
\hline Kanpur & 121.26 & 9.46 & 506.23 & 12.57 & 8.16 & 0.60 & 56.19 & 15.70 & 73.66 & 11.48 & 63.45 \\
\hline $\mathrm{SE}(\mathrm{m})$ & 6.19 & 1.41 & 11.45 & 0.21 & 0.03 & 0.02 & 1.49 & 0.61 & 4.85 & 0.71 & 10.51 \\
\hline$C D(p=0.05)$ & 17.62 & 4.00 & 32.54 & 0.603 & 0.10 & 0.05 & 4.23 & 1.74 & 13.78 & 2.02 & 29.88 \\
\hline
\end{tabular}

The cultivar influence on soil chemical and biological properties is given in Table 3 . It was found that the available N was higher in rhizosphere soils of both BG 372 and BG 256 cultivars over the bulk soils from all the locations. Available P content was higher in rhizosphere soils of BG 256. On the other hand, the available $\mathrm{K}$ and organic carbon was higher in rhizosphere soil of BG 372. The soil pH of rhizosphere and bulk soil is near alkaline. EC content of rhizosphere soil of BG 256 is slightly higher $\left(0.76 \mathrm{dS} \mathrm{m}^{-1}\right)$. The dehydrogenase, urease and alkaline phosphatase activity was higher in rhizosphere soil of BG 256 whereas $\beta$-glucosidase activity was higher in rhizosphere soil of BG 372 . Our results clearly indicate the cultivar influence on soil chemical and enzyme activities. On the contrary, microbial biomass carbon was higher in bulk soil. 
Table 3

Cultivar influence on nutrient availability and soil microbial activity of bulk and rhizosphere soils of chickpea

\begin{tabular}{|c|c|c|c|c|c|}
\hline & Bulk Soil & Rhizosphere soil of BG 256 & Rhizosphere soil of BG 372 & SE (m) & $\mathrm{CD}(\mathrm{P}=0.05)$ \\
\hline Available $\mathrm{N}\left(\mathrm{kg} \mathrm{ha}^{-1}\right)$ & 144.49 & 189.55 & 154.71 & 3.58 & 10.18 \\
\hline Available $\mathrm{P}\left(\mathrm{kg} \mathrm{ha}^{-1}\right)$ & 16.09 & 18.42 & 13.27 & 0.81 & 2.31 \\
\hline Available K $\left(\mathrm{kg} \mathrm{ha}^{-1}\right)$ & 427.10 & 321.02 & 520.82 & 6.61 & 18.79 \\
\hline Organic carbon $\left(\mathrm{g} \mathrm{kg}^{-1}\right)$ & 10.51 & 9.33 & 11.11 & 0.12 & 0.35 \\
\hline $\mathrm{pH}$ & 8.02 & 7.77 & 8.06 & 0.02 & 0.06 \\
\hline$E C\left(d s m^{-1}\right)$ & 0.53 & 0.76 & 0.52 & 0.01 & 0.03 \\
\hline $\begin{array}{l}\text { Dehydrogenase } \\
\text { ( } \mu \text { g TPF/g soil/h) }\end{array}$ & 43.75 & 57.26 & 48.00 & 0.86 & 2.44 \\
\hline $\begin{array}{l}\text { Urease } \\
\left(\mu \mathrm{g} \mathrm{NH}_{4}{ }^{-} \mathrm{N} \mathrm{g}^{-1} \text { soil h}^{-1}\right)\end{array}$ & 21.60 & 23.01 & 21.15 & 0.35 & 1.01 \\
\hline $\begin{array}{l}\text { Alkaline Phosphatase } \\
\left(\mu \mathrm{g} \mathrm{PNP} \mathrm{g}^{-1} \text { soil }^{-1} \text { ) }\right.\end{array}$ & 120.21 & 129.12 & 109.88 & 2.80 & 7.95 \\
\hline $\begin{array}{l}\beta \text {-Glucosidase } \\
\left(\mu \mathrm{g} \mathrm{g}^{-1} \text { soil } \mathrm{h}^{-1}\right)\end{array}$ & 12.08 & 13.85 & 15.70 & 0.41 & 1.17 \\
\hline $\begin{array}{l}\text { MBC } \\
\left(\mu g^{-1} \text { soil day }^{-1}\right)\end{array}$ & 90.24 & 51.57 & 87.79 & 6.07 & 17.25 \\
\hline
\end{tabular}

The biomass content of soils varied from as low as 49.55 nmoles $\mathrm{g}^{-1}$ soil in BG 256 rhizosphere soil of Pune site 2 to as high as $1948.18 \mathrm{nmoles} \mathrm{g}^{-1}$ soil in New Delhi site II rhizosphere soil of BG 372 (Fig. 1). It was observed that the BG 372 cultivar had a more pronounced effect on biomass content in rhizosphere soils of Dharwad (1132.44 nmoles $\mathrm{g}^{-1}$ soil), Jharkhand (1391 nmoles g ${ }^{-1}$ soil), New Delhi site II (1948 $\mathrm{nmoles} \mathrm{g}^{-1}$ soil), Pune site I (404.26 nmoles g $^{-1}$ soil) and Pune site II ( 608.25 nmoles $\mathrm{g}^{-1}$ soil) as compared to BG 256 rhizosphere soils from same locations. Exception to this were BG 256 rhizosphere soils of New Delhi site I ( 1616.15 nmoles $\mathrm{g}^{-1}$ soil) and Gangwa (1048 $\mathrm{nmoles} \mathrm{g}^{-1}$ soil). The ratio of Gram positive to Gram negative bacteria varied from a lower ratio of 0.67 in bulk soil of Jharkhand site to a higher ratio of 4.87 in rhizosphere soil of Dharwad with BG 372 cultivar (Fig. 2). The ratio of Gram positive to Gram negative bacteria was found to be influenced both by soil types and cultivarswith most rhizosphere soils corresponding to higher ratios. On the whole, the Gram positive to Gram negative ratio was higher in bulk soils from New Delhi site II (2.31) and Varanasi (3.53) but the maximum impact was found in BG 256 rhizosphere soil of Jharkhand (4.76).

The quantification of 16S rDNA and nifH gene copy numbers using qPCR in the present study estimated the abundance of total bacterial and the diazotroph communities in bulk and rhizosphere soils (Table 4). The $16 \mathrm{~S}$ eubacterial rRNA gene copy numbers were around $5.26 \times 10^{6} \mathrm{~g}^{-1}$ soil where as nifH copy numbers was around $1.36 \times 10^{5} \mathrm{~g}^{-1}$ soil. The $16 \mathrm{~S}$ rDNA and nifH gene copy number varied significantly across all locations. The New Delhi site I significantly differed from other sites in 16S (Fig. 3) and nifH copy number (Fig. 4). The 16S rDNA and gene copy numbers were in general found higher in bulk soils (Supplementary table 1). The nifH copy number was not influenced by cultivar at New Delhi Site I, Gangwa, Pune Site I and Pune Site II whereas at New Delhi Site II and Kanpur soils, the cultivar BG 372 influence on nifH copy number is evident. The PCA analysis showed the cultivar BG256 (63.94 \% variation) to be the most significant attribute to determine eubacterial abundance whereas BG 372 (60.42\% variation) was the most influential attribute of diazotrophic abundance (Supplementary table $2 \& 3$ ). The average ratio of nifH to eubacteria $16 \mathrm{~S}$ gene copy numbers also varied with cultivarand soil type (Table 5 ). Rhizosphere soil bacterial community of BG 256 at Pune site II and Kanpur showed highest ratio. The rhizosphere soil of cultivar BG 372 showed 10 -fold decrease in nifH/16S ratio at New Delhi site I, New Delhi site II, Gangwa, Pune site I, and Kanpur site where as BG 256 rhizosphere soil showed 10 -fold decline in Rajnandgaon, Gangwa, Pune Site I.

Table 4

Population densities of eubacteria and diazotrophic communities associated with bulk and rhizosphere soil of Chickpea estimated by qPCR

\begin{tabular}{|c|c|c|c|c|}
\hline & \multicolumn{2}{|c|}{ 16S rDNA (gene copies $\mathrm{g}^{-1}$ soil) } & \multicolumn{2}{|c|}{ nifH (gene copies $\mathrm{g}^{-1}$ soil) } \\
\hline & Range & Average ( \pm SD) & Range & Average $( \pm S D)$ \\
\hline Bulk Soil & $1.81 \cdot 10^{5}-1.43 \cdot 10^{7}$ & $7.50 \pm 5.53 \cdot 10^{6}$ & $3.38 \cdot 10^{3}-3.63 \cdot 10^{5}$ & $1.30 \pm 1.27 \cdot 10^{5}$ \\
\hline BG 256 & $4.54 \cdot 10^{5}-1.82 \cdot 10^{7}$ & $5.65 \pm 5.47 \cdot 10^{6}$ & $1.04 \cdot 10^{2}-8.52 \cdot 10^{5}$ & $1.69 \pm 2.88 \cdot 10^{5}$ \\
\hline BG372 & $5.77 \cdot 10^{4}-1.08 \cdot 10^{7}$ & $2.63 \pm 3.38 \cdot 10^{6}$ & $3.67 \cdot 10^{3}-4.07 \cdot 10^{5}$ & $1.11 \pm 1.37 \cdot 10^{5}$ \\
\hline
\end{tabular}

Page 6/15 
Table 5

Relative densities of diazotrophic microbial communities in chickpea rhizosphere (nifH gene)

\begin{tabular}{|llll|}
\hline \multirow{2}{*}{ Locations } & \multicolumn{3}{l}{ Ratio (nifH/16S rDNA) } \\
\cline { 2 - 4 } & Bulk Soil & BG 256 & BG 372 \\
\hline Dharwad & $6.88 \cdot 10^{-1}$ & $2.25 \cdot 10^{-2}$ & $7.56 \cdot 10^{-2}$ \\
Rajnandgaon & $8.97 \cdot 10^{-2}$ & $1.64 \cdot 10^{-1}$ & $6.36 \cdot 10^{-2}$ \\
\hline New Delhi site I & $2.36 \cdot 10^{-2}$ & $2.32 \cdot 10^{-2}$ & $1.22 \cdot 10^{-1}$ \\
\hline New Delhi site II & $9.19 \cdot 10^{-3}$ & $9.79 \cdot 10^{-3}$ & $7.20 \cdot 10^{-2}$ \\
\hline Gangwa & $5.33 \cdot 10^{-3}$ & $1.10 \cdot 10^{-2}$ & $1.54 \cdot 10^{-2}$ \\
\hline Varanasi & $2.20 \cdot 10^{-2}$ & $1.36 \cdot 10^{-2}$ & $5.08 \cdot 10^{-2}$ \\
\hline Pune site I & $6.55 \cdot 10^{-3}$ & $1.01 \cdot 10^{-2}$ & $1.77 \cdot 10^{-2}$ \\
\hline Pune site II & $1.45 \cdot 10^{-2}$ & $2.30 \cdot 10^{-4}$ & $2.32 \cdot 10^{-2}$ \\
\hline Kanpur & $2.72 \cdot 10^{-4}$ & $3.51 \cdot 10^{-4}$ & $1.56 \cdot 10^{-2}$ \\
\hline All qPCR data are in gene copies g-1 $\mathrm{soil}^{-2}$ & \\
\hline
\end{tabular}

Average Well Color Development (AWCD), an indicator of carbon substrate utilization pattern was found to be higher for rhizosphere soils than bulk soils (Table 6). The measurement of AWCD at $72 \mathrm{~h}$ displayed that the BG 372 rhizosphere soil of Dharwad was found to have highest value whereas the bulk soil of Jharkhand showed the lowest. The BG 256 rhizosphere soil exhibited consistently higher AWCD in most of the soils as compared to bulk and BG 372 rhizosphere soils except at Dharwad soil. The carbon substrate utilization pattern was found to be lower in bulk soils except for Pune site 1, Varanasi and Kanpur bulk soils where they exhibited higher substrate utilization pattern. The metabolic activity of bulk and rhizosphere soils of different locations is depicted in heatmap (Fig. 5). Of the $31 \mathrm{C}$-substrates, 26 were utilized by the microbial communities of bulk soils of Varanasi and Kanpur. In the rhizosphere soils of the two cultivars, C-substrate utilization ranged from 22 to 29 (BG 372) and 27 to 29 (BG 256). AWCD and Mclntosh index at $72 \mathrm{~h}$ was higher in rhizosphere soils of BG 372 at all soil types except Pune site I (bulk soil showed higher index) however, Shannon diversity was more or less similar in bulk and rhizosphere soil of all locations.

Table 6

Microbial activity and diversity of microbial communities (based on BIOLOG analysis at 72h) associated with bulk and rhizosphere soils of chickpea in different soil types.

\begin{tabular}{|c|c|c|c|c|c|c|c|c|c|}
\hline & \multicolumn{3}{|c|}{ AWCD } & \multicolumn{3}{|c|}{ Shannon Diversity $(\mathrm{H})$} & \multicolumn{3}{|c|}{ Mclntosh Evenness (U) } \\
\hline & Bulk & BG256 & BG372 & Bulk & BG256 & BG372 & Bulk & BG256 & BG372 \\
\hline Dharwad & 0.99 & 1.65 & 1.92 & 3.36 & 3.38 & 3.40 & 7.87 & 9.66 & 10.50 \\
\hline Rajnandgaon & 0.19 & 1.38 & 1.28 & 3.35 & 3.30 & 3.25 & 1.49 & 6.18 & 9.11 \\
\hline New Delhi site I & 0.29 & 1.71 & 1.41 & 3.37 & 3.34 & 3.27 & 5.17 & 7.71 & 10.31 \\
\hline New Delhi site II & 0.39 & 1.73 & 1.65 & 3.37 & 3.34 & 3.35 & 4.56 & 7.63 & 10.44 \\
\hline Gangwa & 0.51 & 1.50 & 1.22 & 3.36 & 3.32 & 3.26 & 4.94 & 7.61 & 9.82 \\
\hline Varanasi & 1.41 & 1.49 & 1.38 & 3.34 & 3.35 & 3.32 & 9.01 & 7.34 & 7.63 \\
\hline Pune site I & 1.13 & 1.51 & 1.09 & 3.29 & 3.30 & 3.30 & 8.16 & 8.54 & 9.64 \\
\hline Pune site II & 0.51 & 1.61 & 1.14 & 3.34 & 3.25 & 3.21 & 4.61 & 7.25 & 9.85 \\
\hline Kanpur & 1.63 & 1.85 & 1.54 & 3.36 & 3.34 & 3.32 & 10.43 & 10.42 & 11.12 \\
\hline
\end{tabular}

The dry weight of plant biomass varied from $143 \mathrm{mg} \mathrm{plant}^{-1}$ in BG 372 cultivar grown in Haryana soil to $1287.33 \mathrm{mg} \mathrm{plant}^{-1}$ in same cultivar grown in Pune site 1 soil (Table 7). Further, in relation to plant dry weight both BG 372 and BG 256 cultivar sperformed equally in all locations, except for BG 256 grown in Haryana soil (967.67 mg plant ${ }^{-1}$ ) and BG 372 grown in Pune site 1 (1287.33 mg plant ${ }^{-1}$ ) as well as Kanpur (575.33 mg plant ${ }^{-1}$ ) soils showed higher plant biomass with respect to one another. Among the different soils, highest biomass was accumulated with Pune site 1 (936.33 mg plant ${ }^{-1}$ ) and least was recorded at New Delhi site 1 (329.33 mg plant $^{-1}$ ). The total plant N content in both the cultivars ranged from $2.34 \%$ BG 372 plants grown in Haryana soil and 5.85\% BG 256 plants grown in Pune site 1 soil. The plant N content (Table 7) was higher in BG 256 cultivar grown among Haryana (3.21\%) and Pune site 1 (5.85\%) soils whereas BG 372 showed higher plant N content when grown in New Delhi site 2 (5.62\%) and Kanpur (4.85\%) soils. Though the cultivar alone was found non-significant with respect to plant $\mathrm{N}$ content, soil type has significantly affected the plant $\mathrm{N}$. The chickpea plants grown with Haryana soil recorded lowest $\mathrm{N}$ content $(2.77 \%)$ which is at par with Jharkhand location (2.98\%). Higher N content was observed with the Pune site 2 (5.53 \%). The total plant P content (Table 7) estimated in both the cultivarsranged from a lower value of $0.75 \%$ in BG 256 plants grown in Kanpur soil to a higher value of $2.43 \%$ in BG 
372 plants grown in same Kanpur soil. The plant P content was found to be higher in BG 372 cultivar when grown in Pune site 1(1.57\%) and Kanpur (2.43\%) soils. Also, it was higher in BG 256 cultivar when grown in New Delhi site 2 (2.02\%), Haryana (1.52\%) and Pune site 2 (2.21\%) soils. Among the different locations, Pune site 1 recorded highest P content (1.89\%) whereas lowest P content was observed with New Delhi site 1 (1.18\%).

Table 7

Plant growth and nutrient uptake of chickpea cultivars grown under different soils

\begin{tabular}{|c|c|c|c|c|c|c|c|c|c|}
\hline & \multicolumn{3}{|c|}{ Plant dry weight (mg plant ${ }^{-1}$ ) } & \multicolumn{3}{|c|}{ N content $(\%)$} & \multicolumn{3}{|c|}{ P content (\%) } \\
\hline & BG 372 & BG 256 & Mean (L) & BG 372 & BG 256 & Mean (L) & BG 372 & BG 256 & Mean (L) \\
\hline Dharwad & 4.38 & 1.95 & 3.17 & 3.13 & 3.14 & 3.14 & 1.68 & 1.74 & 1.71 \\
\hline Jharkhand & 0.73 & 12.52 & 6.63 & 3.13 & 2.84 & 2.98 & 1.61 & 1.62 & 1.62 \\
\hline New Delhi site 1 & 0.00 & 0.90 & 0.45 & 5.21 & 5.19 & 5.20 & 1.20 & 1.17 & 1.18 \\
\hline New Delhi site 2 & 0.25 & 0.94 & 0.60 & 5.62 & 4.70 & 5.16 & 1.62 & 2.02 & 1.82 \\
\hline Haryana & 0.00 & 1.49 & 0.75 & 2.34 & 3.21 & 2.77 & 1.18 & 1.52 & 1.35 \\
\hline Varanasi & 1.34 & 0.34 & 0.84 & 3.85 & 3.69 & 3.77 & 1.64 & 1.57 & 1.61 \\
\hline Pune site 1 & 2.05 & 0.00 & 1.02 & 2.88 & 5.85 & 4.36 & 1.57 & 1.17 & 1.37 \\
\hline Pune site 2 & 0.53 & 0.35 & 0.44 & 5.84 & 5.23 & 5.53 & 1.56 & 2.21 & 1.89 \\
\hline Kanpur & 0.54 & 0.00 & 0.27 & 4.85 & 2.40 & 3.63 & 2.43 & 0.75 & 1.59 \\
\hline \multirow[t]{2}{*}{ Mean (G) } & 1.09 & 2.06 & & 4.09 & 4.03 & & 1.61 & 1.53 & \\
\hline & $\mathrm{L}$ & G & LXG & L & G & LXG & $\mathrm{L}$ & G & LXG \\
\hline $\mathrm{SE}(\mathrm{m})$ & 0.78 & NS & 1.10 & 0.09 & NS & 0.13 & 0.018 & 0.009 & 0.026 \\
\hline$C D(P=0.05)$ & 2.24 & NS & 3.17 & 0.27 & NS & 0.38 & 0.053 & 0.025 & 0.075 \\
\hline
\end{tabular}

\section{Discussion}

Soil microbial communities are key players for the maintenance of soil function, health and fertility as they are involved in vital processes such as organic matter decomposition, soil structure formation and cycling of nutrients in the environment. Together with an increasing emphasis on eco-friendly and low input agricultural practices; there is also a rising interest to study soil microbial communities for enhancing crop growth and health. In the present study,we analyzed the impact of soil types and chickpea cultivars on rhizosphere microbial community function and abundance using CLPP and qPCR. The cultivars and soil types have been shown to influence the microbial diversity, microbial metabolic potential and abundance in chickpea rhizosphere, as evidenced by the soil type and plant species dependent variation in the rhizosphere-associated microbial communities, and their activities (Inceoglu et al. 2012 ; Qiao et al. 2017). Our earlier study has shown genotype variation in symbiotic performance of Rhizobium (Naik et al. 2017). Microbial community composition differs among the rhizosphere compartments, with diversity of these communities increasing from root towards bulk soil (Donn et al. 2015). Rhizosphere is a biological hotspot differs substantially from the surrounding bulk soil on the ground of their physicochemical properties. This marked difference in microenvironments of rhizosphere and bulk soil is due to root exudations and plant absorption. The carbon-rich rhizosphere select specific microbial populations and supports the establishment of microorganisms, and the root exudate components vary with soil type and cultivar (Jones et al. 2009).

PLFA is a culture-independent method used to determine the microbial community composition by analyzing signature molecules present in the cell membranes of the microorganisms (Frostegard et al.1991). PLFAs can be used as indicators of microbial stress and are used to track changes in soil microbial community composition (White et al. 1996; Kaur et al. 2005). This technique can determine microbial biomass, shift in microbial community structure and activities and physiological status of the sample. PLFA technique can differentiate various taxonomic groups of soil microorganisms and eliminate the bias associated with cultivation-dependent method. Bacterial biomarkers include specifically, 15:0 (Pentadecanoic acid), 16:0 (Hexadecanoic acid), 17:0 (Heptadecanoic acid), 16:1 w7c ((9Z)-9-Hexadecenoic acid), 18:1 w7c ((11Z)-11-Octadecenoic acid), a15:0 (12-Methyltetradecanoic acid), a17:0 (14-Methylhexadecanoic acid), i14:0 (11-Methyltridecanoic acid), i15:0 (13-Methyltetradecanoic acid), i16:0 (14-Methylpentadecanoic acid), and i17:0 (15Methylhexadecanoic acid). Furthermore, i14:0 (11-Methyltridecanoic acid), i15:0 (13-Methyltetradecanoic acid), i16:0 (14-Methylpentadecanoic acid), i17:0 (15-Methylhexadecanoic acid), a15:0 (12-Methyltetradecanoic acid) and a17:0 (14-Methylhexadecanoic acid) were Gram-positive (G+) bacteria biomarkers and 16:1 w7c ((9Z)-9-Hexadecenoic acid), 18:1 w7c ((11Z)-11-Octadecenoic acid), cy17:0 (Methylenehexadecanoic acid), cy19:0 (Methyleneoctadecanoic acid) were Gram-negative (G-) bacteria biomarkers (Zhao 2016). In the present study, the microbial biomass estimated as total PLFA biomarkers also showed difference among the soil types and cultivars. A marked increase in the total concentration and composition of PLFAs was seen in rhizosphere soils as compared to the bulk soils which can be attributed to root induced shifts in microbial activity (Neumann and Romheld 2002). Except for Dharwad and Jharkhand sites, the ratio of Gram + to Gram - bacteria was higher in the bulk soil than rhizosphere which confirms the studies on root exudates enriched rhizosphere soil favor the Gram - bacteria, leading to their increased growth in plant rhizosphere (Chen et al. 2016). A previous study also showed that Gram bacteria is positively correlated in the presence of higher soil $\mathrm{N}$ and organic residues (Buyer et al.2010; Bray et al. 2012).

Quantification of bacterial communities using qPCR technique is a robust method which provides an estimate of the abundance of the bacterial community in a sample without any culturable discrepancies and bias. Eubacterial and diazotrophic population densities of bulk and rhizosphere soils of chickpea cultivarsgrown in different soil types were analyzed through qPCR. 16S rRNA gene is a taxonomic unit for bacteria and nifH is the structural gene coding for 
nitrogenase enzyme present in diazotrophs (Newton 2013). The diazotrophic communities are key players of nitrogen cycle particularly with legume crops as they are grown under low N. Different soil types are thought to harbor specific microbial communities (Fierer and Jackson 2006) and nifH copy number can detect shifts in diazotroph community structure (Pereira-e-Silva et al. 2011). We evidenced differential distribution of nifH copy number across the soil types which probably is due to changes in the physicochemical characteristics such as $\mathrm{pH}, \mathrm{EC}$, organic carbon and available nitrogen content.It has been shown that the nifH copy number varies with organic carbon content and soil chemistry (Collavino et al. 2014) and significant difference in the abundance and composition of diazotroph community among different soils can lead to the variation in rate of biological nitrogen fixation (Chen et al. 2019). The influence of cultivar on relative density of diazotrophic abundance was observed as the plant genotype also affect the indigenous functional microbial guilds of rhizosphere (Liu et al. 2019). Our earlier study also showed a clear cut evidence that microbial populations in the spatial compartments of field grown chickpea are distinct (Swarnalakshmi and Annapurna 2019) and diazotrophic abundance was more in rhizosphere soil than bulk soil (Sharma et al. 2020).

The CLPP was proposed (Garland and Mills 1991) as a rapid screening means to characterize microbial communities from different habitats using BIOLOG plate and is being used to assess microbial community function and functional diversity (Preston-Mafham et al. 2002; Rutgers et al. 2016; Al-Dhabaan and Bakhali 2017). In the present study, there was clear discrimination between the carbon utilization patterns between bulk and rhizosphere soils evaluated using BIOLOG assay. The lower AWCD and Mclntosh evenness in bulk soil is presumably due to the rhizosphere influence on microbial community function. Further, microbial activities between bulk and rhizosphere soils of two chickpea cultivar showed significant difference. This difference may be due to presence of diverse microbial communities and their metabolic capabilities. Further carbohydrates, amino acids, carboxylic acids were the substrates chiefly accountable for this distinction as plants may differ in exudation of these compounds (Grayston 1997).

In our study, both soil type and cultivar influenced the available N, P, K and organic carbon content of the soil. The nutrient content was higher in rhizosphere soil in contrast to bulk soil. This could be due to root-induced organic matter decomposition and mineral weathering and this result was consistent with the findings of Ai et al. (2012). The available N, P, K in the soil increased the activity of soil microorganisms (Ge et al. 2008) but Treseder (2008) has demonstrated a contrast result where soil nutrient status had little or no effect on either soil microbial activity or diversity. Soil pH and EC of rhizosphere and bulk soil was not significantly different, which was in contrast to results obtained by Fan (2017).

The microbial metabolic activity measured in terms of soil enzymes also varied significantly with cultivar and soil type. The extracellular enzyme secreted by the soil microorganisms are the negotiators of organic matter formation and decomposition. Our results indicated that both soil types as well as soil fractions (rhizosphere and bulk soil) differed significantly for the enzyme activities and were not equally distributed between them. Variation in enzyme activities in different soil fraction was reported by Ai et al. (2012). In their study, higher activities of dehydrogenase and $\beta$-glucosidase enzymes was observed in rhizosphere soils whereas alkaline phosphatase and urease enzymes had higher activities in bulk soil. Plant cultivar also significantly influenced microbial activities in soil. The genetic variation in plant cultivar can attribute differences in root exudation which in turn caused changes in rhizosphere microbial community function (Monchgesang et al. 2016).

Principal component analysis (Fig. 6) and K-means non-hierarchical cluster mapping (Fig. 7) showed three groups of locations (soil types) in which group 1 consist of New Delhi site I, group 2 comprised Pune Site I, Pune Site II and New Delhi site II and group 3 had Kanpur, Varanasi, Haryana, Dharwad and Jharkhand locations. In New Delhi site I (group 1), the most important contributors are available nitrogen, available phosphorus and alkaline phosphatase. In group 2, pH is the significant contributor followed by available K. Dehydrogenase and urease activities influenced the group 3 locations.Collectively, our results suggest the presence of distinct microbial composition and distribution patterns among the various bulk and rhizosphere soils which may result in potential function differentiation (Fan 2017). Soil type (Zachow et al. 2008) as well as cultivar (Graner et al. 2003) have a considerable influence on the structure and function of microbial communities inhabiting the chickpea rhizosphere. Hence, there is no general conclusion about the key player involved and both soil type (Da Silva et al. 2003) and cultivar (Milling et al. 2004) can dominate depending on the biotic and abiotic conditions of the system. From the previous studies, it can be established that the microbial community composition in the rhizosphere is influenced by a complex interaction between soil type, plant type and root zone location (Marschner 2001).

The plant biomass and plant $\mathrm{N}$ content were insignificant with cultivar however soil types and interactive effect of soil and cultivarshowed significant influence. Plant P content was influenced by both cultivarand soil types. The plant nutrient was found to vary significantly with soil types whereas within locations the nutrient content was less affected by the cultivars. Chekanai (2018) showed that the cultivareffect was not significant with plant $\mathrm{N}$ and $\mathrm{P}$ content of biomass. The two cultivarsshowed little or no response with regard to plant dry weight, $\mathrm{N}$ and $\mathrm{P}$ content in same soil type. However, between the soil types the chickpea growthand nutrient status was found to differ, indicating soil type to be the key factor to influence the chickpea growth across various locations. The study signifies the interaction between soil type and cultivar together has more impact on soil microbial activities rather than the soil type and cultivar alone.

\section{Declarations}

Conflict of interest The authors declare no competing interests.

Ethical approval The authors declare no ethical conflicts.

Informed consent Authors declare that they have consented to participate in the manuscript and publish it.

\section{Acknowledgements}

We acknowledge the Indian Council of Agricultural Research (ICAR) funded projects ICAR-AINP Research Program on Soil diversity and biofertilizer and ICARBNF project for sponsoring this research. SG gratefully acknowledges the help for BIOLOG facility provided by Dr. Devyani Tipre, Department of Microbiology \& 
Biotechnology, Gujarat University, India.

\section{References}

1. Ai C, Liang G, Sun J, Wang X, Zhou W (2012) Responses of extracellular enzyme activities and microbial community in both the rhizosphere and bulk soil to long-term fertilization practices in a fluvo-aquic soil. Geoderma 174:330-338

2. Al-Dhabaan FAM, Bakhali AH (2017) Analysis of the bacterial strains using Biolog plates in the contaminated soil from Riyadh community. Saudi J Bio Sci 24(4):901-906

3. Bligh EG, Dyer WJ (1959) A rapid method of total lipid extraction and purification. Can J Biochem Physiol 37:911-917

4. Bray SR, Kitajima K, Mack MC (2012) Temporal dynamics of microbial communities on decomposing leaf litter of 10 plant species in relation to decomposition rate. Soil Biol Biochem 49:30-37

5. Buyer JS, Teasdale JR, Roberts DP, Zasada IA, Maul JE (2010) Factors affecting soil microbial community structure in tomato cropping systems. Soil Biol Biochem 42:831-841

6. Casida LE (1977) Microbial metabolic activity in soil as measured by dehydrogenase determinations. Soil Sci 34:630-636

7. Chekanai V, Chikowoa R, Vanlauwe B (2018) Response of common bean (Phaseolus vulgaris L.) to nitrogen, phosphorus and rhizobia inoculation across variable soils in Zimbabwe. Agric Ecosyst Environ 266:167-173

8. Chen J, Shen W, Xu H, Li Y, Luo T (2019) The Composition of nitrogen-fixing microorganisms correlates with soil nitrogen content during reforestation: a comparison between legume and non-legume plantations. Front Microbio 10:508

9. Chen ZJ, Tian YH, Zhang Y, Song BR, Li HC, Chen ZH (2016) Effects of root organic exudates on rhizosphere microbes and nutrient removal in the constructed wetlands. Ecol Eng 92:243-250

10. Collavino MM, Tripp HJ, Frank IE, Vidoz ML, Calderoli PA, Donato M, Zehr JP, Aguilar OM (2014) nifH pyrosequencing reveals the potential for locationspecific soil chemistry to influence $\mathrm{N}_{2}$-fixing community dynamics. Environ Microbiol 16:3211-3223

11. Da Silva KRS, Salles JF, Seldin L, d Van Elsas JD (2003) Application of a novel Paenibacillus-specific PCR-DGGE method and sequence analysis to assess the diversity of Paenibacillus spp. in the maize rhizosphere. J Microbiol Methods 54: 213-231

12. Donn S, Kirkegaard JA, Perera G, Richardson AE, Watt M (2015) Evolution of bacterial communities in the wheat crop rhizosphere. Environ Microbiol 17:610-621

13. Eivazi F, Tabatabai MA (1988) Glucosidases and galactosidases in soils. Soil Biol Biochem 20::601-606

14. Fan K, Cardona C, Li Y, Shi Y, Xiang X, Shen C, Wang H, Gilbert JA, Chu H (2017) Rhizosphere-associated bacterial network structure and spatial distribution differ significantly from bulk soil in wheat crop fields. Soil Biol Biochem 113:275-284

15. FAOSTAT, Food and Agricultural Organization of the United Nations, Statistics Division. (data was generated using up to 2019FAOSTAT database, http://www.fao.org/faostat/en/\#data), Retrieved December, 2020

16. Fierer N, Jackson JA, Vilgalys R, Jackson RB (2005) Assessment of soil microbial community structure by use of taxon-specific quantitative PCR assays. Appl Environ Microbiol 71:4117-4120

17. Fierer N, Jackson RB (2006) The diversity and biogeography of soil bacterial communities. PNAS 103:626-631

18. Frostegard A, Tunlid A, Baath E (1991) Microbial biomass measured as total lipid phosphate in soils of different organic content. J Microbiol Methods 14:151-163

19. Garland JL, Mills AL (1991) Classification and characterization of heterotrophic microbial communities on the basis of patterns of community-level solecarbon-source utilization. Appl Environ Microbiol 57:2351-2359

20. Garland JL (1996) Analytical approaches to the characterization of samples of microbial communities using patterns of potential C source utilization. Soil Biol Biochem 28:213-221

21. Ge Y, Zhang JB, Zhang LM, Yang M, He JZ (2008) Long-term fertilization regimes affect bacterial community structure and diversity of an agricultural soil in northern China. J Soils Sediment 8:43-50

22. Gich FB, Amer E, Figueras JB, Abella CA, Balaguer MD, Poch M (2000) Assessment of microbial community structure changes by amplified ribosomal DNA restriction analysis (ARDRA). Internatl Microbiol 3:103-106

23. Graner G, Persson P, Meijer J, Alstrom S (2003) A study on microbial diversity in different cultivars of Brassica napus in relation to its wilt pathogen, Verticillium longisporum. FEMS Microbiol Lett 29:269-276

24. Grayston SJ, Vaughan D, Jones D (1997) Rhizosphere carbon flow in trees, in comparison with annual plants: the importance of root exudation and its impact on microbial activity and nutrient availability. Appl Soil Ecol 5:29-56

25. Guckert JB, White DC (1986) Phospholipid ester-linked fatty acid analysis in microbial ecology, p 455-459. In: F Megusar and G Kantar (eds.) Perspectives in microbial ecology, Proc. Fourth Intl Symp Microb Ecol Ljubljana. American Society for Microbiology, Washington

26. Hu Y, Xiang D, Veresoglou SD, Chen F, Chen Y, Hao Z, Zhang X, Chen B (2014) Soil organic carbon and soil structure are driving microbial abundance and community composition across the arid and semi-arid grasslands in northern China. Soil Biol Biochem 77:51-57

27. Inceoglu O, Salles JF, van Elsas JD (2012) Soil and cultivar type shape the bacterial community in the potato rhizosphere. Microbial Ecol 63:460-470

28. Jackson ML (1973) Soil Chemical Analysis, Prentice Hall of India Private Limited, 1st edition, New Delhi, India

29. Jones DL, Nguyen C, Finlay RD (2009) Carbon flow in the rhizosphere: carbon trading at the soil-root interface. Plant Soil 321:5-33

Page $10 / 15$ 
30. Kaur A, Chaudhary A, Kaur A, Choudhary R, Kaushik R (2005) Phospholipid fatty acid a bio indicator of environment monitoring and assessment in soil ecosystem. Curr Sci 89:1103-1112

31. Kwak MJ, Kong HG, Choi K et al (2018) Rhizosphere microbiome structure alters to enable wilt resistance in tomato. Nat Biotech 36:1100-1109

32. Liu F, Hewezi T, Lebeis SL, Pantalone V, Grewal PS, Staton ME (2019) Soil indigenous microbiome and plant genotypes cooperatively modify soybean rhizosphere microbiome assembly. BMC Microbiol 19:1-19

33. Lundberg DS, Teixeira PJ (2018) Root-exuded coumarin shapes the root microbiome. PNAS 115:5629-5631

34. Marschner P, Yang CH, Lieberei R, Crowley DE (2001) Soil and plant specific effects on bacterial community composition in the rhizosphere. Soil Biol Biochem 33:1437-1445

35. Mendes R, Kruijt M, De Bruijn I, Dekkers E et al (2011) Deciphering the rhizosphere microbiome for disease-suppressive bacteria. Science 332:1097-1100

36. Miller KM, Ming TJ, Schulze AD, Withler RE (1999) Denaturing gradient gel electrophoresis (DGGE): a rapid and sensitive technique to screen nucleotide sequence variation in populations. BioTech 27:1016-1030

37. Milling A, Smalla K, Xaver F, Maidl K, Schloter M, Munch JC (2004) Effects of transgenic potatoes with an altered starch composition on the diversity of soil and rhizosphere bacteria and fungi. Plant Soil 266:23-39

38. Mittal N, Virdi JS (2002) Methods for studying microbial diversity including molecular techniques. Status and Potential Applications, Microbial Diversity, p 134

39. Monchgesang S, Strehmel N, Schmidt S, Westphal L, Taruttis F, Muller E, Herklotz S, Newmann S, Scheel D (2016) Natural variation of root exudates in Arabidopsis thaliana-linking metabolomic and genomic data. Sci Rep 6:29033

40. Naik SKS, Annapurna K, Annu K, Vithal L, Reddy KK, Swarnalakshmi K (2017) Soybean (Glycine max) genotype-mediated variation in the symbiotic performance of Rhizobium. Ind J Agri Sci 87(8):1051-1054

41. Neumann G, Romheld V (2002) Root-induced changes in the availability of nutrients in the rhizosphere. In: Waisel Y, Eshel A, Kafkafi U (eds) Plant roots: the hidden half, third edn. Marcel Dekker, Inc, New York, pp 617-649

42. Newton PCD (2013) A reduced fraction of plant N derived from atmospheric $\mathrm{N}$ (\%Ndfa) and reduced rhizobial nifH gene numbers indicate a lower capacity for nitrogen fixation in nodules of white clover exposed to long-term $\mathrm{CO}_{2}$ enrichment. Biogeosci 10:8269-8281

43. Nichols D (2007) Cultivation gives context to the microbial ecologist. FEMS Microbiol Ecol 60:351-357

44. Olsen S, Cole C, Watanabe F, Dean L (1954) Estimation of available phosphorus in soils by extraction with sodium bicarbonate. In: USDA Circular Nr 939, US Gov. Office, Washington, D.C. Print.

45. Pereira-e-Silva MC, Semenov AV, van Elsas JD, Salles JF (2011) Seasonal variation in diversity and abundance of diazotrophic communities across soils. FEMS Microbiol Ecol 77:57-68

46. Pii Y, Borruso L, Brusetti L, Crecchio C, Cesco S, Mimmo T (2016) The interaction between iron nutrition, plant species and soil type shapes the rhizosphere microbiome. Plant Physiol Biochem 99:39-48

47. Poly F, Monrozier LJ, Bally R (2001) Improvement in the RFLP procedure for studying the diversity of nifH genes in communities of nitrogen fixers in soil. Res Microbiol 152:95-103

48. Preston-Mafham J, Boddy L, Randerson PF (2002) Analysis of microbial community functional diversity using sole-carbon-source utilization profiles-a critique. FEMS Microbiol Ecol 42:1-14

49. Qiao Q, Wang F, Zhang J, Chen Y et al (2017) The variation in the rhizosphere microbiome of cotton with soil type, genotype and developmental stage. Sci Rep 7(1):1-10

50. Reinhold-Hurek B, Bünger W, Burbano CS, Sabale M, Hurek T (2015) Roots shaping their microbiome: global hotspots for microbial activity. Ann Rev Phytopathol 53:403-424

51. Rutgers M, Wouterse M, Drost SM, Breure AM, Mulder C, Stone D (2016) Monitoring soil bacteria with community-level physiological profiles using Biolog ECO-plates in the Netherlands and Europe. Appl Soil Eco 97:23-35

52. Sasse J, Martinoia E, Northen T (2018) Feed your friends: do plant exudates shape the root microbiome? Trends Plant Sci 23:25-41

53. Satyaprakash Ch, Annapurna K (2006) Diversity of a soybean bradyrhizobial population adapted to an Indian soil. J Plant Biochem Biotech 15(1):27-32

54. Sharma R, Pooniya V, Bisaria VS, Swarnalakshmi K, Sharma S (2020) Bioinoculants play a significant role in shaping the rhizospheric microbial community: a field study with Cajanus cajan. World J Microbiol Biotechnol 36(3):1-17

55. Smalla K, Wieland G, Buchner A, Zock A, Parzy J, Kaiser S, Roskot N, Heuer H, Berg G (2001) Bulk and rhizosphere soil bacterial communities studied by denaturing gradient gel electrophoresis: Plant-dependent enrichment and seasonal shifts revealed. Appl Environ Microbiol 67:4742-4751

56. Smith JL, Doran JW (1996) Measurement and use of pH and electrical conductivity for soil quality analysis. In: Doran JW and Jones AJ, Eds, Methods for assessing Soil Quality. Soil Sci Soc Am J Madison 49

57. Subbiah B, Asija G (1956) A rapid procedure for the estimation of available nitrogen in soils. Curr Sci 25:259-260

58. Swarnalakshmi K, Annapurna K (2019) Compositional changes of bacterial communities associated with field grown chickpea. Regional Young Investigators' meeting held at NIPGR, New Delhi during August 6-7, 2019

59. Swarnalakshmi K, Yadav V, Tyagi D, Dhar DW, Kannepalli A, Kumar S (2020) Significance of plant growth promoting rhizobacteria in grain legumes: growth promotion and crop production. Plants 9: p.1596

60. Tabatabai MA, Bremner JM (1969) Use of p-nitrophenyl phosphate for assay of soil phosphatase activity. Soil Biol Biochem 1:301-307

61. Tabatabai MA, Bremner JM (1972) Assay of urease activity in soils. Soil Biol Biochem 4:479-487

Page $11 / 15$ 
62. Treseder KK (2008) Nitrogen additions and microbial biomass: A meta-analysis of ecosystem studies. Ecol Lett 11:1111-1120

63. Vance ED, Brookes PC, Jenkinson DS (1987) An Extraction method for measuring soil microbial biomass carbon. Soil Biol Biochem 19:703-704

64. Walkley AJ, Black IA (1934) Estimation of soil organic carbon by the chromic acid titration method. Soil Sci 37:29-38

65. Walley FL, Boahen SK, Hnatowich G, Stevenson C (2005) Nitrogen and phosphorous fertility management for desi and kabuli chickpea. Can J Plant Sci $85: 73-79$

66. White DC, Stair JO, Ringelberg DB (1996) Quantitative comparisons of in situ microbial biodiversity by signature biomarker analysis. J Ind Microbiol Biotechnol 17:185-196

67. Yuen SH, Pollard AG (1953) Determination of nitrogen in soil and plant materials: Use of boric acid in the micro-kjeldahl method. J Sci Food Agric 4:490496

68. Zachow C, Tilcher R, Berg G (2008) Sugar beet-associated bacterial and fungal communities show a high indigenous antagonistic potential against plant pathogens. Microbial Ecol 55:119-129

69. Zhao S, Lic K, Zhoua W, Qiua S, Huanga S, Hea P (2016) Changes in soil microbial community, enzyme activities and organic matter fractions under longterm straw return in north-central China. Agric Ecosyst Environ 216:82-88

70. Zhu X, Zhu B (2015) Diversity and abundance of soil fauna as influenced by long-term fertilization in cropland of purple soil, China. Soil Tillage Res $146: 39-46$

\section{Figures}

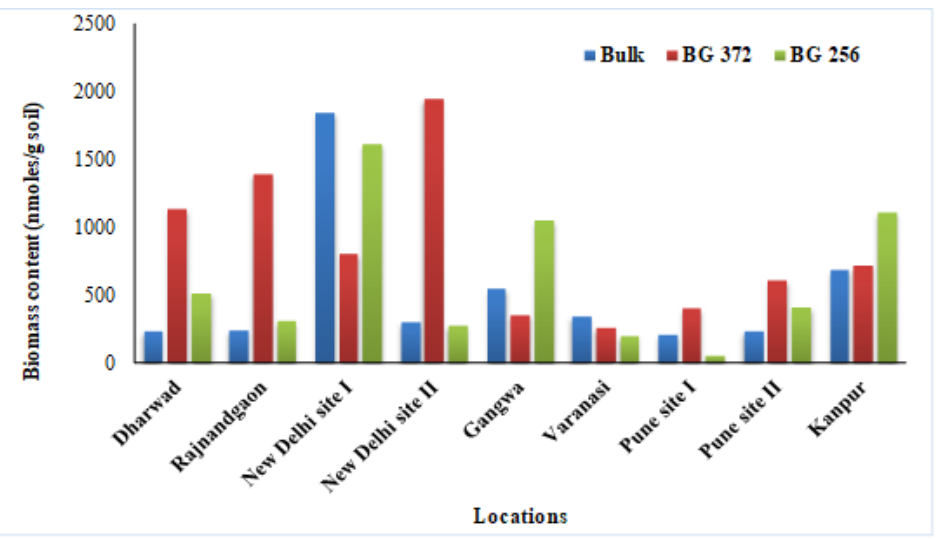

\section{Figure 1}

Soil type and genotypic influence on biomass content of bulk and chickpea rhizosphere soil by PLFA

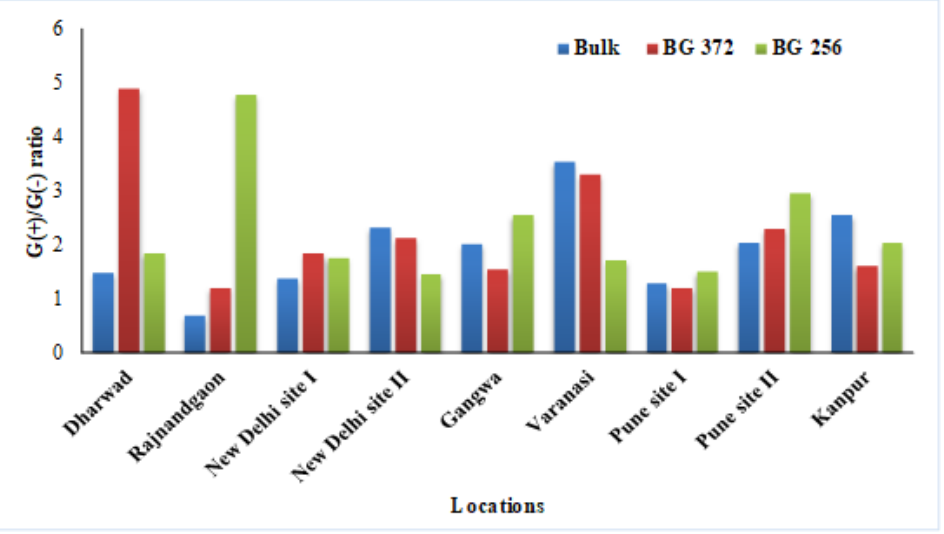

Figure 2

Soil type and genotypic influence on $\mathrm{G}(+) / \mathrm{G}(-)$ ratio of bulk and chickpea rhizosphere soil 


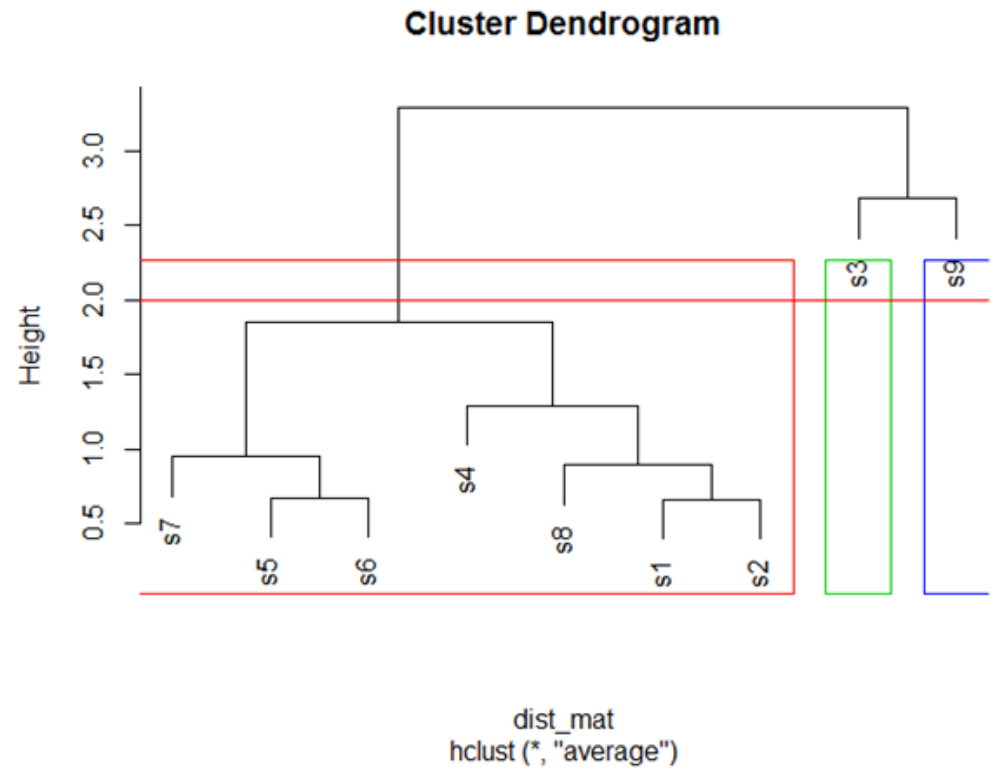

Figure 3

Hierarchical agglomerative cluster analysis of 16S rDNA copy numbers across different sites (s1- Dharwad, s2 - Rajnandgaon, s3 - New Delhi site I, s4 - New Delhi site II, s5 - Gangwa, s6 - Varanasi, s7 - Pune site I, s8 - Pune site II, s9 - Kanpur)

\section{Cluster Dendrogram}

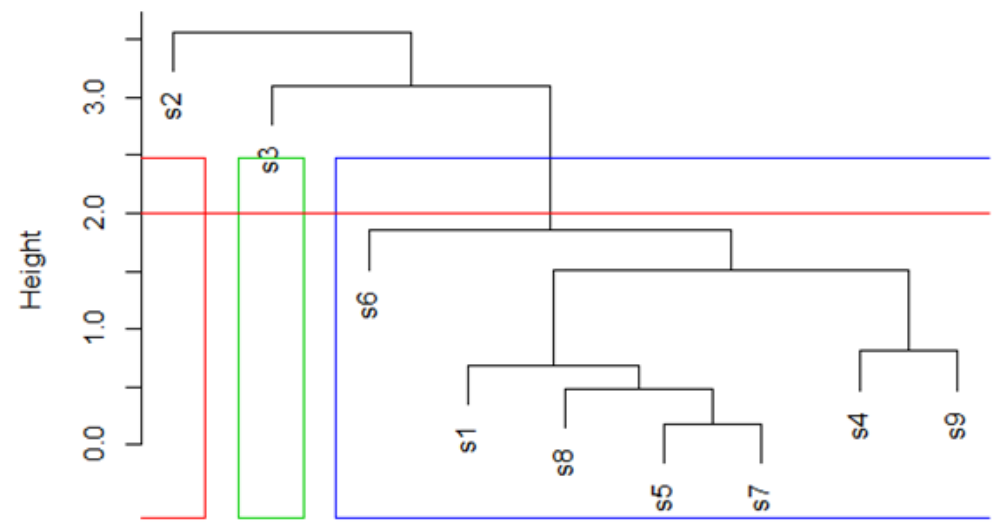

dist_mat
hclust (*," "average")

Figure 4

Hierarchical agglomerative cluster analysis of nifH copy numbers across different sites (s1- Dharwad, s2 - Rajnandgaon, s3 - New Delhi site I, s4 - New Delhi site II, s5 - Gangwa, s6 - Varanasi, s7 - Pune site I, s8 - Pune site II, s9 - Kanpur) 


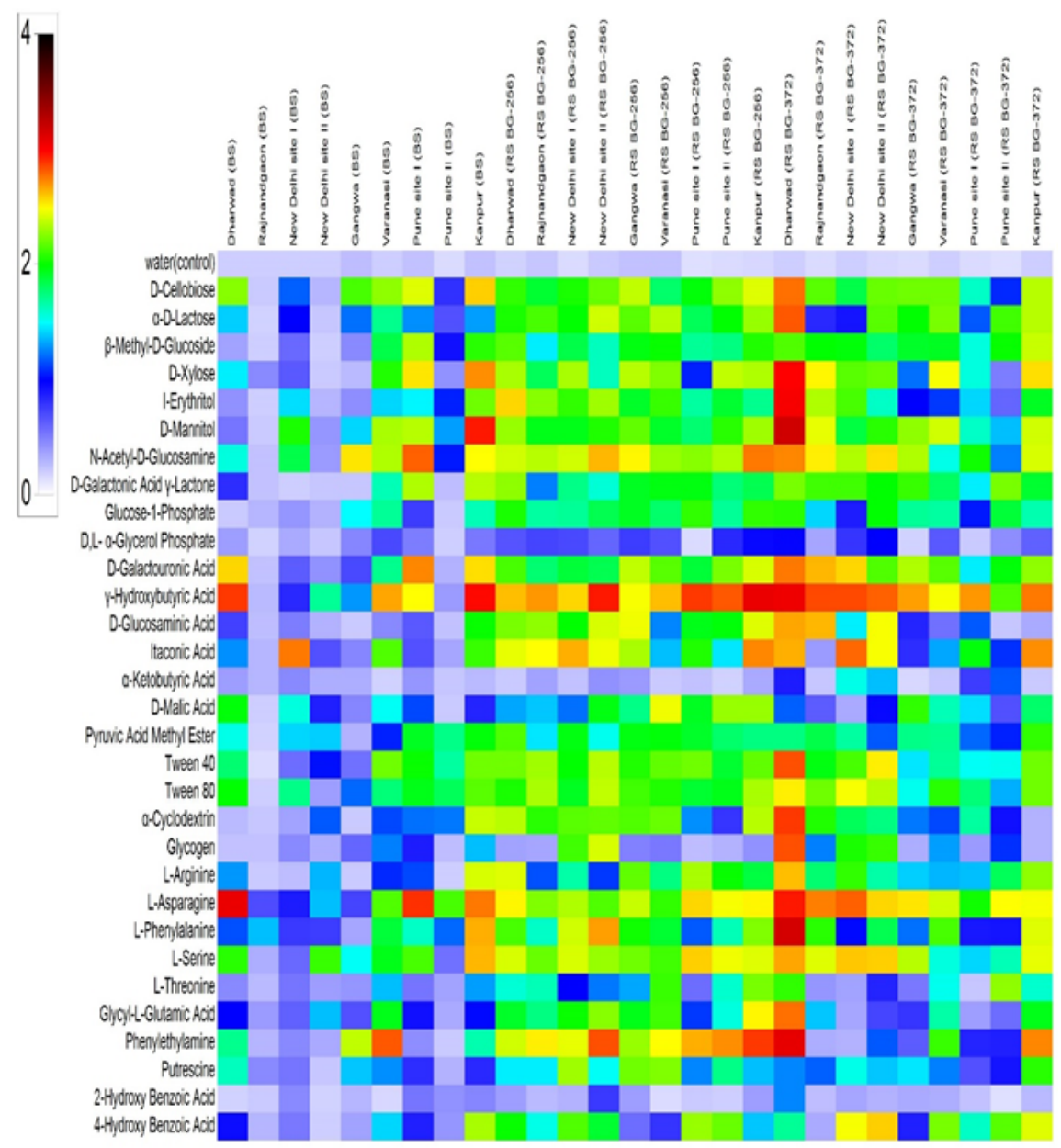

\section{Figure 5}

Heatmap comparison of substrate utilization pattern of bulk (BS) and rhizosphere soils (RS) of Chickpea in different soil types. Light blue corresponds to low metabolic rate, dark red corresponds to high metabolic rate.

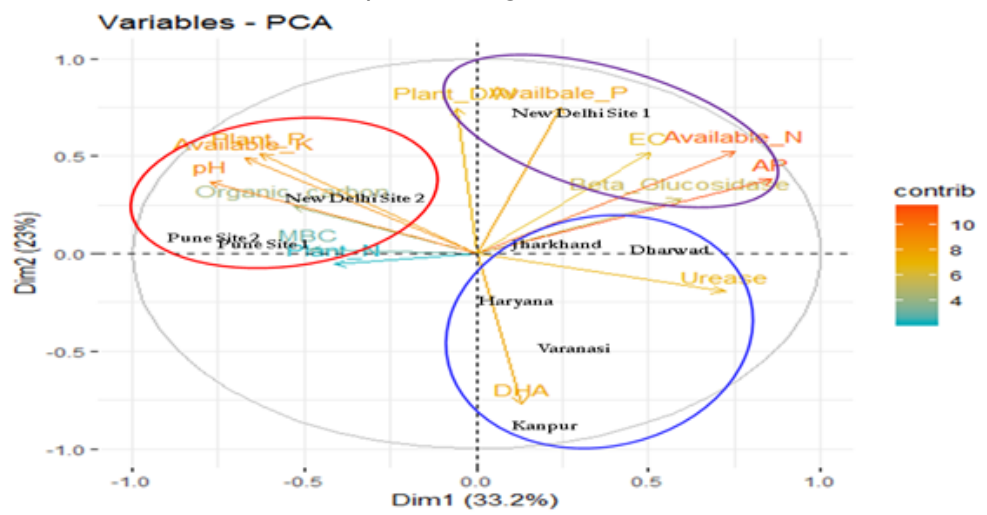

\section{Figure 6}

PCA biplot grouped soil types based on chemical, biological and plant parameters 


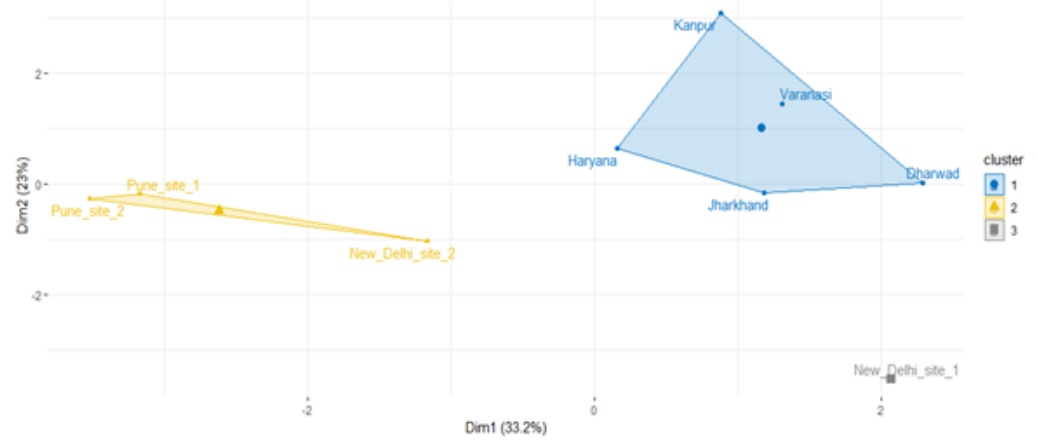

Figure 7

Custer plot of soil types based on $\mathrm{K}$ means hierarchical clustering method

\section{Supplementary Files}

This is a list of supplementary files associated with this preprint. Click to download.

- 4SupplementaryTables.docx 